Prepared in cooperation with the Louisiana Department of Transportation and Development

\title{
Water Resources of St. John the Baptist Parish, Louisiana
}

\section{Introduction}

Information concerning the availability, use, and quality of water in St. John the Baptist Parish, Louisiana (fig. 1), is critical for proper water-supply management. The purpose of this fact sheet is to present information that can be used by water managers, parish residents, and others for stewardship of this vital resource. Information on the availability, past and current use, use trends, and water quality from groundwater and surface-water sources in the parish is presented.

Previously published reports (see References Cited section) and data stored in the U.S. Geological Survey's National Water Information System (http://waterdata.usgs.gov/nwis) are the primary sources of the information presented here.
In 2010 about 67.5 million gallons per day $(\mathrm{Mgal} / \mathrm{d})$ of water were withdrawn in St. John the Baptist Parish. Surface-water sources accounted for about 80 percent of all withdrawals, whereas groundwater sources accounted for 20 percent (table 1). Withdrawals for industrial use accounted for 90 percent of the total water withdrawn. Other categories of use included public supply, rural domestic, livestock, and general irrigation (table 2). Water-use data collected at 5-year intervals from 1960 to 2010 indicated that water withdrawals in the parish peaked in 1990 at about $110 \mathrm{Mgal} / \mathrm{d}$ (fig. 2). From 1980 to 1985 , surface-water withdrawals for industrial use declined from 93.7 to $35.0 \mathrm{Mgal} / \mathrm{d}$ before increasing to $91.0 \mathrm{Mgal} / \mathrm{d}$ in 1990 .

${ }^{1}$ Water-withdrawal data are based on estimated or reported site-specific data and aggregated data, which are distributed to sources. For a full description of water-use estimate methodology, see "Data Collection" in Sargent (2011). Tabulation of numbers across text and tables may result in different totals because of rounding; nonrounded numbers are used for calculation of totals.

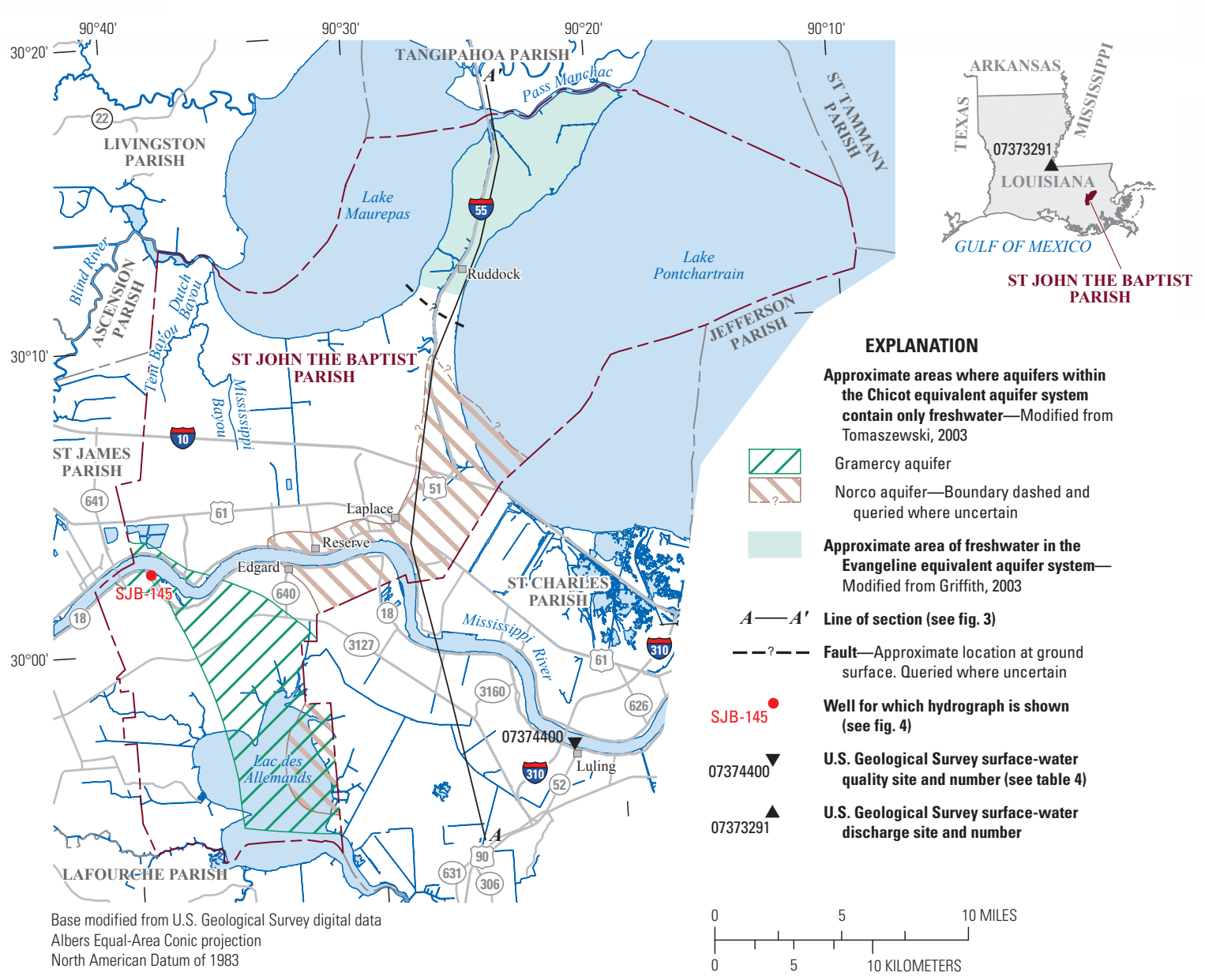

Figure 1. Location of study area, St. John the Baptist Parish, Louisiana. 
Table 1. Water withdrawals, in million gallons per day, by source in St. John the Baptist Parish, Louisiana, 2010 (Sargent, 2011; B.P. Sargent, unpub. data, 2011).

\begin{tabular}{lcc}
\hline \multicolumn{1}{c}{$\begin{array}{c}\text { Aquifer, aquifer system, or } \\
\text { surface-water body }\end{array}$} & Groundwater & Surface water \\
\hline Gramercy aquifer & 4.43 & \\
Norco aquifer & 5.10 & \\
Gonzales-New Orleans aquifer & 0.04 & \\
Evangeline equivalent & 3.93 & \\
$\quad$ aquifer system & & 53.97 \\
Mississippi River & & 0.08 \\
Miscellaneous streams & & 54.04 \\
Total & 13.50 & \\
\hline
\end{tabular}

Table 2. Water withdrawals, in million gallons per day, by use category in St. John the Baptist Parish, Louisiana, 2010 (modified from Sargent, 2011).

$[<$, less than $]$

\begin{tabular}{lccr}
\hline \multicolumn{1}{c}{ Use category } & Groundwater & $\begin{array}{c}\text { Surface } \\
\text { water }\end{array}$ & Total \\
\hline Public supply & 3.93 & 2.53 & 6.46 \\
Industrial & 9.49 & 51.44 & 60.93 \\
Rural domestic & 0.09 & 0.00 & 0.09 \\
Livestock & 0.00 & $<0.01$ & $<0.01$ \\
General irrigation & 0.00 & 0.07 & 0.07 \\
\cline { 2 - 4 } Total & 13.50 & 54.04 & 67.55 \\
\hline
\end{tabular}

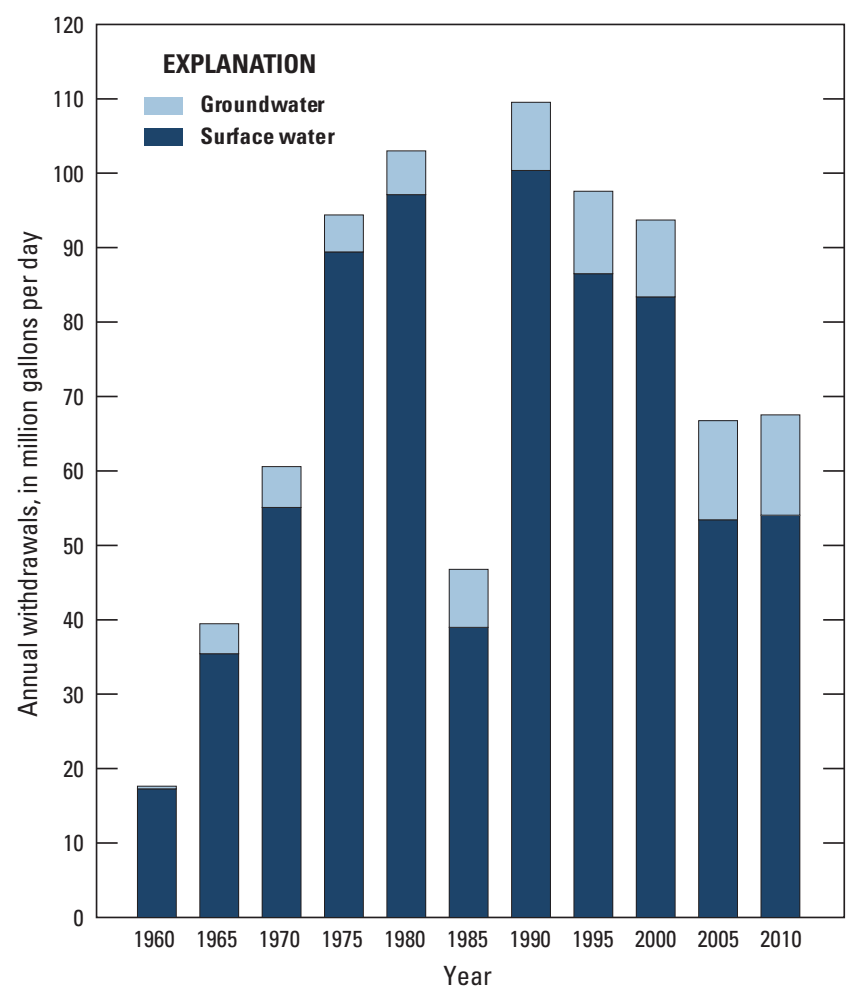

Figure 2. Water withdrawals in St. John the Baptist Parish, Louisiana, 1960-2010 (Sargent, 2011).

\section{Groundwater Resources}

The primary fresh groundwater sources (water with a chloride concentration of 250 milligrams per liter [mg/L] or less) in St. John the Baptist Parish include the Chicot equivalent aquifer system and the Evangeline equivalent aquifer system (fig. 3 ). The Jasper equivalent aquifer system, which underlies the Evangeline equivalent aquifer system, may also contain limited supplies of freshwater in northern St. John the Baptist Parish, but it is not considered a primary source of fresh groundwater in the parish and is not discussed further.

Depth to the base of freshwater varies greatly within the parish. Freshwater is present to depths of about 700 feet (ft) below the National Geodetic Vertical Datum of 1929 (NGVD 29) (fig. 3) south of the fault near Ruddock (fig. 1) in the Chicot equivalent aquifer system. North of the fault, freshwater is present at depths from about $200 \mathrm{ft}$ to as much as $900 \mathrm{ft}$ below NGVD 29 in the Chicot equivalent aquifer system and from about 2,300 to 3,100 ft below NGVD 29 in the Evangeline equivalent aquifer system (fig. 3); between these depths, the aquifer systems generally contain saltwater (water with a chloride concentration greater than $250 \mathrm{mg} / \mathrm{L}$ ).

Recharge to the freshwater areas of the Chicot and Evangeline equivalent aquifer systems results from infiltration of precipitation in areas where they outcrop or connect to outcropped aquifers to the north and northwest of Lake Pontchartrain. Recharge also comes through the clay confining layers that separate adjacent aquifers and in localized areas, where adjacent aquifers are merged or in hydraulic connection to unnamed shallow aquifers. These shallow aquifers receive recharge from infiltration of precipitation and from localized hydraulic connections to the Mississippi River (Dial and Kilburn, 1980; Dial and Sumner, 1989). Discharge from aquifers results from well pumping and from flow through hydraulic connections and confining layers to adjacent aquifers. State well-registration records listed 112 active water wells screened in the Chicot and Evangeline equivalent aquifer systems in St. John the Baptist Parish in 2009, including 52 domestic, 29 irrigation, 17 industrial, and 14 public supply (Louisiana Department of Natural Resources, 2009). In 2010, groundwater withdrawals for various uses included public supply, industrial, and rural domestic (table 2).

\section{The Chicot Equivalent Aquifer System}

In St. John the Baptist Parish, the primary aquifers of the Chicot equivalent aquifer system are the Gramercy, Norco, and Gonzales-New Orleans aquifers (fig. 3). Unnamed shallow sands may also contain limited supplies of freshwater. Figure 1 shows the locations of freshwater within the Gramercy and Norco aquifers in the Parish.

\section{Gramercy Aquifer}

In the areas of St. John the Baptist Parish where the Gramercy aquifer is present and contains freshwater (fig. 1), the top of the aquifer is about 175 to $200 \mathrm{ft}$ below NGVD 29, and the aquifer thickness ranges from less than $100 \mathrm{ft}$ to as much as about $160 \mathrm{ft}$, increasing generally from north to south (Tomaszewski, 2003). Grain size in the aquifer typically grades from fine sand at the top to coarse sand and fine gravel in the middle and lower parts of the aquifer (Dial and Kilburn, 1980). Water levels for well SJB-145 in the Gramercy aquifer fluctuate 


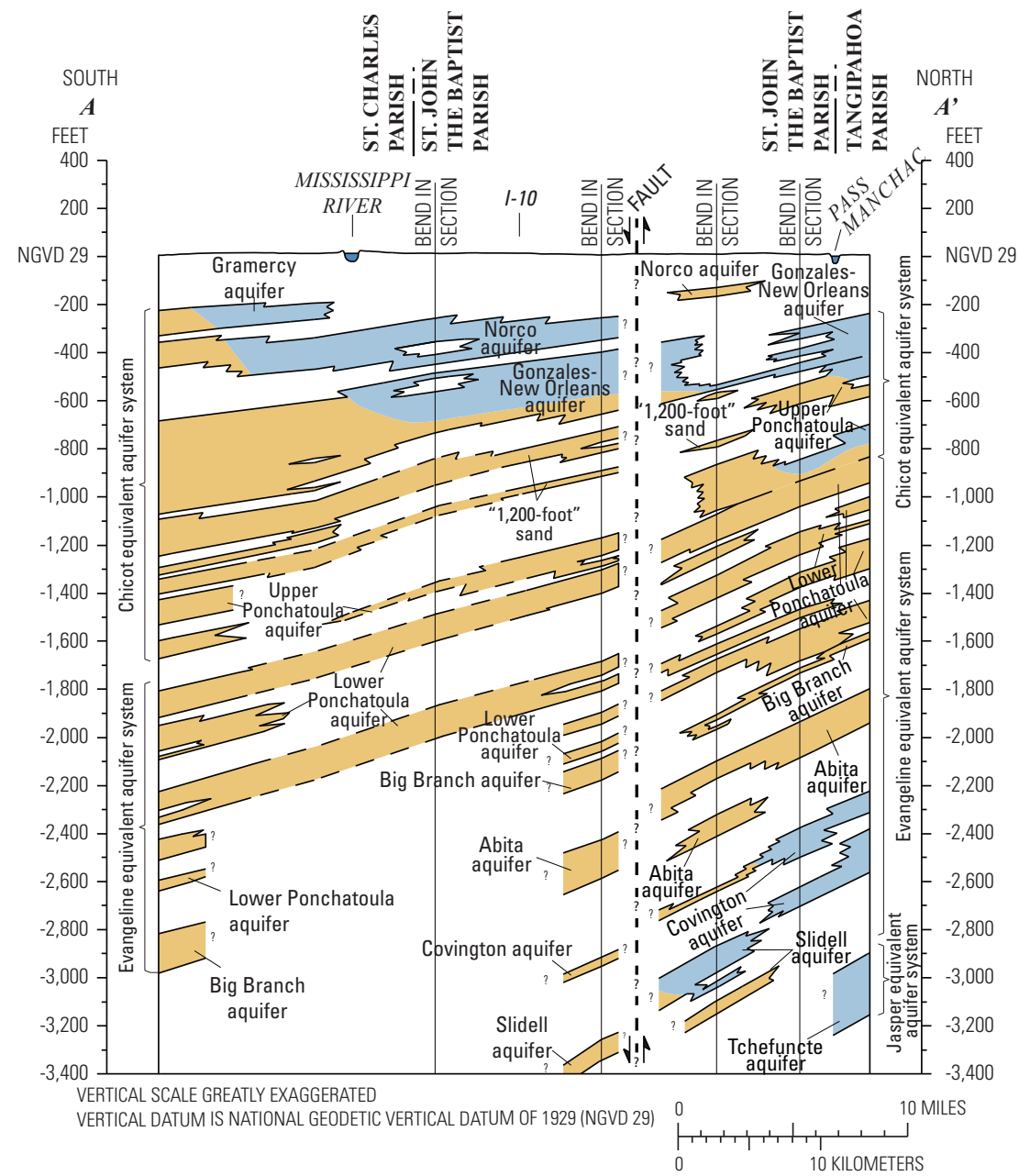

EXPLANATION

Freshwater in sand

Saltwater in sand-Saltwater contains greater than 250 milligrams per liter chloride

\section{$\square \quad$ Clay}

-? Lithologic contact-Separates clay and sand units. Dashed where approximate. Queried where uncertain

Hydrogeologic contact-Defines boundary between conjoined or merged aquifers

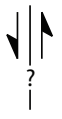

Fault-Dashed where approximately located. Queried where uncertain

Figure 3. South-to-north hydrogeologic section through St. John the Baptist Parish, Louisiana, showing aquifers and clay confining layers (modified from Griffith, 2003). Trace of section shown on figure 1. seasonally (fig. 4), coinciding with stages of the Mississippi River. The magnitude of fluctuation decreases with distance from the Mississippi River (Dial and Kilburn, 1980).

State well-registration records listed 22 active wells screened in the Gramercy aquifer in St. John the Baptist Parish in 2009, including 8 domestic, 6 industrial, 6 irrigation, and 2 public supply. Depths of these wells ranged from 210 to $318 \mathrm{ft}$ below land surface, with a median well depth of $260 \mathrm{ft}$. Reported yields from wells screened in the Gramercy aquifer in St. John the Baptist Parish have ranged from 2 to 2,006 gallons per minute (gal/min) (Louisiana Department of Natural Resources, 2009). In 2010, groundwater withdrawals from the Gramercy aquifer in St. John the Baptist Parish totaled about 4.43 Mgal/d (table 1). All of the withdrawals were for industrial use, except about $0.01 \mathrm{Mgal} / \mathrm{d}$ for rural-domestic use.

Previous reports and limited samples taken from nine wells during 1932-79 indicated that freshwater in the Gramercy aquifer is moderately hard to very hard, ${ }^{2}$ has $\mathrm{pH}$ values ranging from 7.0 to 7.7, and generally exceeds the U.S. Environmental Protection Agency's Secondary Maximum Contaminant Levels ${ }^{3}$ (SMCLs) for color and concentrations of total dissolved solids and iron

\footnotetext{
${ }^{2}$ Hardness ranges, expressed as milligrams per liter of calcium carbonate, are as follows: 0-60, soft; 61-120, moderately hard; 121-180, hard; greater than 180, very hard (Hem, 1985).

${ }^{3}$ The SMCLs are nonenforceable Federal guidelines regarding cosmetic effects (such as tooth or skin discoloration) or aesthetic effects (such as taste, odor, or color) of drinking water. At high concentrations or values, health implications as well as aesthetic degradation might exist. SMCLs were established as guidelines for the States by the U.S. Environmental Protection Agency (1992).
}

(U.S. Geological Survey, 2013). Water quality, however, varies depending on location. Hardness tends to increase with increasing hydraulic connection to Mississippi River water (Hosman, 1972; Dial and Kilburn, 1980).

\section{Norco Aquifer}

In areas of St. John the Baptist Parish where the Norco aquifer is present and contains freshwater (fig. 1), the depth to the top of the aquifer ranges from about $250 \mathrm{ft}$ below NGVD 29 in the northern part of the parish to less than $400 \mathrm{ft}$ below NGVD 29 in the southern part of the parish (Tomaszewski, 2003; Griffith, 2003). The thickness of the aquifer ranges from less than $25 \mathrm{ft}$ north of Laplace to more than $225 \mathrm{ft}$ east of Laplace near the St. Charles Parish line. The upper part of the aquifer contains fine sand, and the lower part contains medium to coarse sand. Fine gravel may also be present in the lower part of the aquifer (Dial and Kilburn, 1980).

State well-registration records listed 46 active wells screened in the Norco aquifer in St. John the Baptist Parish in 2009, including 25 domestic, 9 irrigation, 8 industrial, and 4 public supply. Depths of these wells ranged from 290 to $425 \mathrm{ft}$ below land surface, with a median well depth of $370 \mathrm{ft}$. Reported yields from wells screened in the Norco aquifer in St. John the Baptist Parish have ranged from 22 to 3,460 gal/min (Louisiana Department of Natural Resources, 2009). In 2010, groundwater withdrawals from the Norco aquifer in St. John the Baptist Parish totaled about 5.10 Mgal/d (table 1). All of the withdrawals were for industrial use, except for about $0.04 \mathrm{Mgal} / \mathrm{d}$ for 


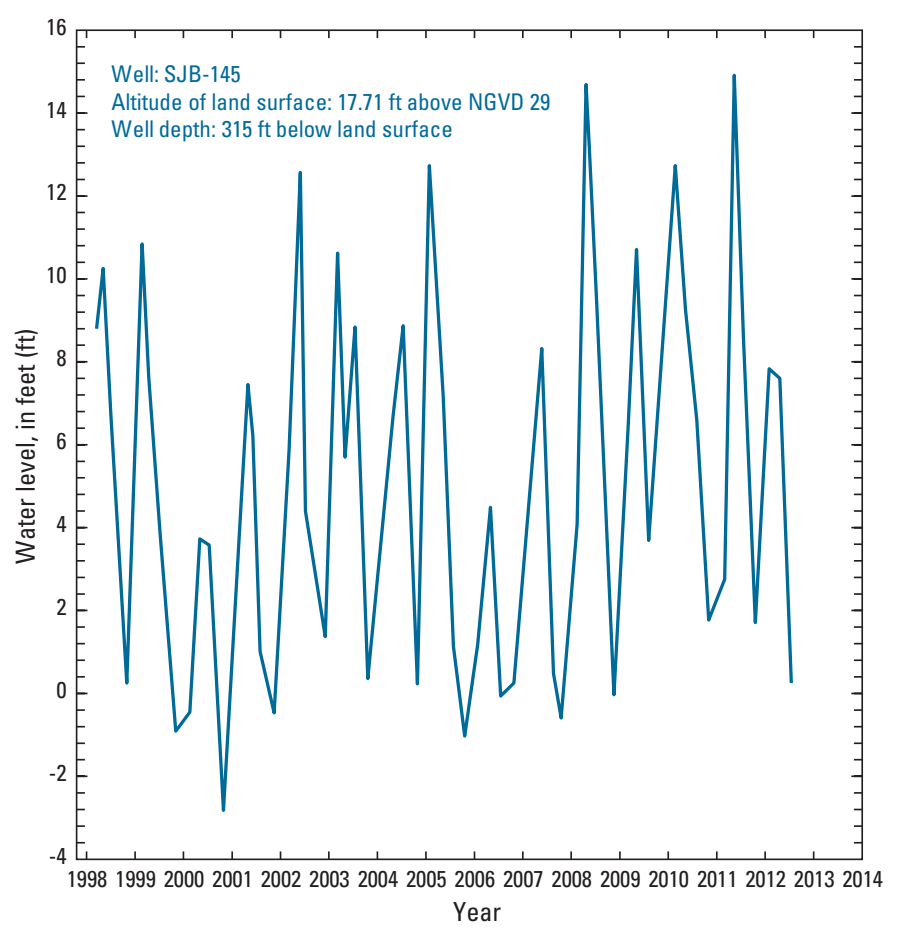

Figure 4. Water levels in well SJB-145 screened in the Gramercy aquifer in St. John the Baptist Parish, Louisiana (see fig. 1 for well location; U.S. Geological Survey, 2009). Land surface and water levels are measured in feet relative to the National Geodetic Vertical Datum of 1929 (NGVD 29).

rural-domestic use. Freshwater samples taken from the Norco aquifer in St. John the Baptist Parish did not exceed the SMCL for $\mathrm{pH}$ but did exceed the SMCLs for color and dissolved solids concentration (table 3 ). Out of a total of 19 samples, 9 were found to be soft in respect to hardness, with the remaining 10 samples ranging from moderately hard to very hard.

\section{Gonzales-New Orleans Aquifer}

The depth to the top of the Gonzales-New Orleans aquifer ranges from about $300 \mathrm{ft}$ below NGVD 29 in the northern part of the parish to about $700 \mathrm{ft}$ below NGVD 29 in the southern part (Tomaszewski, 2003; Griffith, 2003). The sand in the aquifer is very fine to fine (Hosman, 1972). The thickness of the Gonzales-New Orleans aquifer within the parish generally ranges from about 200 to less than $300 \mathrm{ft}$. In eastern and northwestern St. John the Baptist Parish, saltwater underlies the freshwater and is present at the base of the aquifer (fig. 3; Tomaszewski, 2003).

State well-registration records listed 22 active wells screened in the Gonzales-New Orleans aquifer in St. John the Baptist Parish in 2009, including 10 domestic, 5 irrigation, 3 industrial, and 4 public supply. Depths of these wells ranged from 458 to $625 \mathrm{ft}$ below land surface, with a median well depth of $576 \mathrm{ft}$. Reported yields from wells screened in the GonzalesNew Orleans aquifer in St. John the Baptist Parish have ranged from 5 to $260 \mathrm{gal} / \mathrm{min}$ (Louisiana Department of Natural Resources, 2009). In 2010, about $0.04 \mathrm{Mgal} / \mathrm{d}$ were withdrawn from the Gonzales-New Orleans aquifer in St. John the Baptist Parish, mostly for rural-domestic use. During 1960-71, samples taken from 11 wells where freshwater is present in the upper part of the Gonzales-New Orleans aquifer in St. John the Baptist Parish indicated that water is soft, ranges in $\mathrm{pH}$ from 7.7 to 8.4, exceeds the SMCL for color, and frequently exceeds the SMCL for total dissolved solids concentration (U.S. Geological Survey, 2013).

\section{The Evangeline Equivalent Aquifer System}

Freshwater is present in the deepest sand beds of the Evangeline equivalent aquifer system north of the approximate faultline shown on figure 1 . The aquifer system is made up of a series of predominantly fine- to medium-grained sand beds separated by clay layers, which dip to the south (fig. 3). Thickness of individual sand beds varies but is typically from 50 to $200 \mathrm{ft}$ thick (Griffith, 2003).

State well-registration records listed two active wells screened in the Evangeline equivalent aquifer system in St. John the Baptist Parish in 2009; both are public-supply wells located between Lakes Maurepas and Pontchartrain near Ruddock (fig. 1). Depths of these wells are 2,950 and $3,000 \mathrm{ft}$ below land surface. One of the wells reportedly yields 2,120 gal/min (Louisiana Department of Natural Resources, 2009). In 2010, groundwater withdrawals from the Evangeline equivalent aquifer system in St. John the Baptist Parish totaled about 3.93 Mgal/d (table 1). Samples taken during 1971-2005 indicated that freshwater in the Evangeline equivalent aquifer system in St. John the Baptist Parish is soft and exceeds SMCLs for $\mathrm{pH}$ and color (table 3).

\section{Surface-Water Resources}

In 2010, about 54.0 Mgal/d of surface water were withdrawn in St. John the Baptist Parish (table 1). Industrial use accounted for about 95 percent of the surface water withdrawn. Other uses included public supply and general irrigation (table 2). Most surface water withdrawn for industrial use is used for cooling purposes and returned to its source after use (Sargent, 2011). Major water bodies in or bordering the parish include the Mississippi River, Lakes Pontchartrain and Maurepas, and Lac des Allemands (fig. 1). There were no reported water withdrawals from these lakes in 2010.

\section{Mississippi River}

St. John the Baptist Parish is divided by the Mississippi River (fig. 1), which flows in an easterly direction through the parish and is the major source of freshwater in the parish (table 1). In 2010, the river was the source of all surface-water withdrawals for industrial use and public supply in the parish. The average flow of the Mississippi River near Red River Landing (site number 07373291), about 170 mi upstream of Laplace (fig. 1, index map), was about 460,000 cubic feet per second for the period 1928-76 (Wells, 1980). The flow in the Mississippi River at Red River Landing is representative of flows in St. John the Baptist Parish because the section of the river between the landing and the parish is mostly leveed and has no major tributaries or distributaries. 
Table 3. Summary of selected water-quality characteristics of freshwater in the Norco aquifer and Evangeline equivalent aquifer system in St. John the Baptist Parish, Louisiana (U.S. Geological Survey, 2013).

[Values are in milligrams per liter, except as noted. PCU, platinum cobalt units; $\mu \mathrm{S} / \mathrm{cm}$, microsiemens per centimeter; ${ }^{\circ} \mathrm{C}$, degrees Celsius; SU, standard units; $\mathrm{CaCO}_{3}$, calcium carbonate; SMCL, Secondary Maximum Contaminant Level established by the U.S. Environmental Protection Agency (2012); NA, not applicable]

\begin{tabular}{|c|c|c|c|c|c|c|}
\hline & $\begin{array}{l}\text { Color } \\
\text { (PCU) }\end{array}$ & $\begin{array}{c}\text { Specific } \\
\text { conductance, field } \\
\left(\mu \mathrm{S} / \mathrm{cm} \text { at } 25^{\circ} \mathrm{C}\right)\end{array}$ & $\begin{array}{l}\text { pH, } \\
\text { field } \\
\text { (SU) }\end{array}$ & $\begin{array}{l}\text { Hardness } \\
\left(\text { as } \mathrm{CaCO}_{3}\right)\end{array}$ & $\begin{array}{l}\text { Chloride, } \\
\text { filtered } \\
\text { (as CI) }\end{array}$ & $\begin{array}{l}\text { Dissolved } \\
\text { solids, filtered }\end{array}$ \\
\hline \multicolumn{7}{|c|}{ Norco aquifer, 1931-61 (19 wells) } \\
\hline Median & 90 & 1,350 & 7.7 & 72 & 170 & 872 \\
\hline 10th percentile & 40 & 1,290 & 7.4 & 45 & 140 & 753 \\
\hline 90th percentile & 140 & 1,460 & 8.0 & 230 & 210 & 1,040 \\
\hline $\begin{array}{c}\text { Percentage of samples that } \\
\text { do not exceed SMCLs }\end{array}$ & 5 & NA & 100 & NA & 100 & 0 \\
\hline \multicolumn{7}{|c|}{ Evangeline equivalent aquifer system, 1971-2005 (4 wells) } \\
\hline Median & 40 & 821 & 8.9 & 2.9 & 41 & 503 \\
\hline $\begin{array}{c}\text { Percentage of samples that } \\
\text { do not exceed SMCLs }\end{array}$ & 0 & NA & 0 & NA & NA & 42 \\
\hline \multicolumn{7}{|c|}{ SMCLs } \\
\hline & 15 & NA & $6.5-8.5$ & NA & 250 & 500 \\
\hline
\end{tabular}

Water samples analyzed during 1957-99 indicated that water in the Mississippi River at Luling, located about 27 miles downstream from Reserve (fig. 1), generally is hard and does not exceed SMCLs for $\mathrm{pH}$ and concentrations of chloride, sulfate, and iron (table 4). Dissolved oxygen concentrations are generally greater than $5 \mathrm{mg} / \mathrm{L}$, which is considered the minimum value for a diversified population of fresh, warmwater biota, including sport fish (Louisiana Department of Environmental Quality, 2008).

\section{Lakes}

Lake Pontchartrain is a shallow estuarine bay which has a surface area of about 625 square miles $\left(\mathrm{mi}^{2}\right)$ and an average depth of about $11 \mathrm{ft}$. There are appreciable spatial variations in salinity because Lake Pontchartrain is connected to the Gulf of Mexico. The northwestern and western areas of the lake may be fresh during some parts of the year (Demcheck, 1995; Shampine, 1971). Lake Maurepas has a surface area of $91 \mathrm{mi}^{2}$ and an average depth of about $7 \mathrm{ft}$. Salinity in the lake varies because of the influx of saline water from Lake Pontchartrain at the east end of the lake and inflows of freshwater from tributary streams at the western and northern ends of the lake. Because of its salinity, the water in Lake Maurepas is unsuitable for many uses (Shampine, 1971). Lac des Allemands has a surface area of about $23 \mathrm{mi}^{2}$ and an average depth of about $5 \mathrm{ft}$. Water quality in the lake varies spatially and seasonally. Chloride concentrations are moderately high and will occasionally exceed the SMCL of $250 \mathrm{mg} / \mathrm{L}$ (Shampine, 1971).

\section{References Cited}

Demcheck, D.K., 1995, The Lake Pontchartrain watershed-A unique resource of the Louisiana coast: U.S. Geological Survey Fact Sheet 118-95, 2 p.

Dial, D.C., and Kilburn, Chabot, 1980, Ground-water resources of the Gramercy area, Louisiana: Louisiana Department of Transportation and Development, Office of Public Works Water Resources Technical Report no. 24, 39 p.

Dial, D.C., and Sumner, D.M., 1989, Geohydrology and simulated effects of pumpage on the New Orleans aquifer system at New Orleans, Louisiana: Louisiana Department of Transportation and Development Water Resources Technical Report no. 46, 54 p.

Griffith, J.M., 2003, Hydrogeologic framework of southeastern Louisiana: Louisiana Department of Transportation and Development Water Resources Technical Report no. 72, 21 p., 18 pls.

Hem, J.D., 1985, Study and interpretation of the chemical characteristics of natural water (3d ed.): U.S. Geological Survey Water-Supply Paper 2254, 264 p., accessed February 20, 2013, at http://pubs.er.usgs.gov/publication/wsp2254.

Hosman, R.L., 1972, Ground-water resources of the Norco area, Louisiana: Department of Conservation, Louisiana Geological Survey, and Louisiana Department of Public Works Water Resources Bulletin no. 18, 61 p. 
Table 4. Summary of selected water-quality characteristics for the Mississippi River at Luling, Louisiana, 1957-99 (U.S. Geological Survey, 2013).

[Values are in milligrams per liter, except as noted. $\mu \mathrm{S} / \mathrm{cm}$, microsiemens per centimeter; ${ }^{\circ} \mathrm{C}$, degrees Celsius; $\mathrm{SU}$, standard units; $\mathrm{CaCO}_{3}$, calcium carbonate; $\mu \mathrm{g} / \mathrm{L}$, micrograms per liter; <, less than; SMCL, Secondary Maximum Contaminant Level established by the U.S. Environmental Protection Agency (2012); NA, not applicable]

\begin{tabular}{|c|c|c|c|c|c|c|c|c|c|c|}
\hline & $\begin{array}{c}\text { Specific } \\
\text { conductance, } \\
\text { field ( } \mu \mathrm{S} / \mathrm{cm} \\
\text { at } 25^{\circ} \mathrm{C} \text { ) }\end{array}$ & $\begin{array}{l}\text { Oxygen, } \\
\text { dis- } \\
\text { solved }\end{array}$ & $\begin{array}{l}\text { pH, } \\
\text { field } \\
\text { (SU) }\end{array}$ & $\begin{array}{c}\text { Hard- } \\
\text { ness } \\
\text { (as } \\
\mathrm{CaCO}_{3} \text { ) }\end{array}$ & $\begin{array}{l}\text { Calcium, } \\
\text { filtered } \\
\text { (as Ca) }\end{array}$ & $\begin{array}{l}\text { Magne- } \\
\text { sium, } \\
\text { filtered } \\
\text { (as } \mathbf{M g} \text { ) }\end{array}$ & $\begin{array}{l}\text { Sodium, } \\
\text { filtered } \\
\text { (as } \mathrm{Na} \text { ) }\end{array}$ & $\begin{array}{l}\text { Chloride, } \\
\text { filtered } \\
\text { (as CI) }\end{array}$ & $\begin{array}{l}\text { Sulfate, } \\
\text { filtered } \\
\text { (as } \mathrm{SO}_{4} \text { ) }\end{array}$ & $\begin{array}{c}\text { Iron, } \\
\text { filtered } \\
\text { ( } \mu \mathrm{g} / \mathrm{L} \text { as } \\
\mathrm{Fe})\end{array}$ \\
\hline \multicolumn{11}{|c|}{ Mississippi River at Luling ${ }^{1}$} \\
\hline Median & 398 & 8.2 & 7.6 & 150 & 40 & 11 & 21 & 24 & 50 & $<20$ \\
\hline 10th percentile & 298 & 6.2 & 7.2 & 110 & 32 & 7.9 & 12 & 16 & 36 & $<10$ \\
\hline 90th percentile & 500 & 11.2 & 7.9 & 180 & 48 & 15 & 34 & 36 & 71 & 60 \\
\hline Number of samples & 665 & 328 & 656 & 659 & 634 & 636 & 365 & 662 & 662 & 294 \\
\hline $\begin{array}{l}\text { Percent of samples } \\
\text { that do not ex- } \\
\text { ceed SMCLs }\end{array}$ & NA & NA & 99.8 & NA & NA & NA & NA & 100 & 100 & 98.6 \\
\hline \multicolumn{11}{|c|}{ SMCLS } \\
\hline & NA & NA & $6.5-8.5$ & NA & NA & NA & NA & 250 & 250 & 300 \\
\hline
\end{tabular}

Louisiana Department of Environmental Quality, 2008, Environmental Regulatory Code, Title 33, Part IX, Subpart 1: Baton Rouge, Louisiana Department of Environmental Quality, accessed June 9, 2009, at http:www.deq.louisiana.gov/portal/ tabid/1674/Default.aspx.

Louisiana Department of Natural Resources, 2009, Strategic Online Natural Resources Information System (SONRIS): Louisiana Department of Natural Resources database, accessed August 17, 2009, at http://sonris.com/.

Sargent, B.P., 2011, Water use in Louisiana, 2010: Louisiana Department of Transportation and Development Water Resources Special Report no. 17, 135 p.

Shampine, W.J., 1971, Chemical, biological, and physical data for the major lakes and reservoirs in Louisiana: Louisiana Department of Public Works Basic Records Report no. 5, 98 p.

Tomaszewski, D.J., 2003, Ground-water resources along the lower Mississippi River, southeastern Louisiana: Louisiana Department of Transportation and Development Water Resources Technical Report no. 69, 23 p.

U.S. Environmental Protection Agency, 1992, Secondary drinking water regulations - Guidance for nuisance chemicals: U.S. Environmental Protection Agency publication EPA 810/K-92001, 4 p., accessed September 28, 2011, at http://water.epa.gov/ drink/contaminants/secondarystandards.cfm.

U.S. Environmental Protection Agency, 2012, 2012 Edition of the drinking water standards and health advisories: U.S. Environmental Protection Agency publication EPA 822S-12-001, Office of Water, 12 p., accessed August 7, 2012, at http://water.epa.gov/action/advisories/drinking/upload/ dwstandards2012.pdf.

U.S. Geological Survey, 2009, Ground-water levels for Louisiana, [data for USGS 300234090390301 SJB-145]: National Water Information System Web Interface, accessed August 20, 2009, at http://nwis.waterdata.usgs.gov/la/nwis/gwlevels/?site no $=300234090390301$.
U.S. Geological Survey, 2013, Water quality samples for Louisiana: National Water Information System Web Interface, accessed December 3, 2013, at http:/nwis.waterdata.usgs.gov/ la/nwis/qwdata/.

Wells, F.C., 1980, Hydrology and water quality of the lower Mississippi River: Louisiana Department of Transportation and Development, Office of Public Works Water Resources Technical Report no. 21, 83 p.

This fact sheet was published by the U.S. Geological Survey, in cooperation with the Louisiana Department of Transportation and Development (DOTD). Thanks are given to Zahir "Bo" Bolourchi, Director, Water Resources Programs, DOTD, who contributed to the content of the fact sheet.

\section{By Vincent E. White, Lawrence B. Prakken, and Robert B. Fendick, Jr.}

\section{For additional information, contact:}

Director, USGS Lower Mississippi-Gulf Water Science Center 3535 S. Sherwood Forest Blvd., Suite 120

Baton Rouge, LA 70816

E-mail: gs-w-lmg_center_director@usgs.gov

Fax: (225) 298-5490

Telephone: (225) 298-5481

Home Page: http://la.water.usgs.gov 